\title{
New records of the invasive red swamp crayfish Procambarus clarkii (Girard, 1852) (Decapoda: Cambaridae) from Poland
}

\author{
Rafał Maciaszek $^{1, *}$, Maciej Bonk ${ }^{2}$ and Witold Strużyński ${ }^{3}$ \\ ${ }^{1}$ Department of Genetics and Animal Breeding, Faculty of Animal Sciences, Warsaw University of Life Sciences, \\ ul. Ciszewskiego 8, 02-786 Warsaw, Poland \\ ${ }^{2}$ Institute of Nature Conservation, Polish Academy of Sciences, al. Adama Mickiewicza 33, 31-120 Kraków, Poland \\ ${ }^{3}$ Department of Animal Environment Biology, Faculty of Animal Sciences, Warsaw University of Life Sciences, \\ ul. Ciszewskiego 8, 02-786 Warsaw, Poland
}

\section{Received: 9 August 2019 / Accepted: 18 September 2019}

\begin{abstract}
This contribution presents new observations of the red swamp crayfish, Procambarus clarkii in Poland. The species was detected in Żerań Canal and Krasiński Garden in Warsaw (central Poland) where 5 and 2 individuals were collected respectively as well as in Dąbie Pond in Krakow (southern Poland) with total of 4 crayfish observed. These new sites are located approximately $500 \mathrm{~km}$ eastward (Warsaw) and 240$260 \mathrm{~km}$ northward (Krakow) from the nearest European sites where this species has been previously recognised (near Berlin, Germany, Egerszalók and Budapest, Hungary), thus are the furthest north-east records of the species in European open waters. It is likely that the examined stock originates from single introductions, however, presence of the juveniles caught in Warsaw suggests that the population found there may be breeding. The findings are discussed with available literature describing possible ways $P$. clarkii may use to colonize new habitats as well as the impact it has on the invaded ecosystems in general and native crayfish in particular.
\end{abstract}

Keywords: Alien species / freshwater crustacean / ornamental pet trade / inland waters / Central Europe

Résumé - Nouveaux signalements de l'écrevisse de Louisiane envahissante Procambarus clarkii (Girard, 1852) (Decapoda : Cambaridae) en Pologne. Cette contribution présente de nouvelles observations de l'écrevisse de Louisiane, Procambarus clarkii en Pologne. L'espèce a été détectée sur le Canal Żerań et le jardin Krasiński à Varsovie (centre de la Pologne) où 5 et 2 individus ont été prélevés respectivement ainsi que dans l'étang Dąbie à Cracovie (sud de la Pologne) avec au total 4 écrevisses observées. Ces nouveaux sites sont situés à environ $500 \mathrm{~km}$ à l'est (Varsovie) et 240-260 km au nord (Cracovie) des sites européens les plus proches où cette espèce a été précédemment reconnue (près de Berlin, Allemagne, et Budapest, Hongrie), ce qui en fait les plus au nord-est de l'Europe en eaux libres. Il est probable que le stock examiné provient d'introductions uniques, mais la présence de juvéniles capturés à Varsovie suggère que la population qui s'y trouve pourrait s'y reproduire. Les résultats sont discutés avec la littérature disponible décrivant les façons que $P$. clarkii peut utiliser pour coloniser de nouveaux habitats ainsi que l'impact qu'il a sur les écosystèmes envahis en général et les écrevisses indigènes en particulier.

Mots clés : Espèces exotiques / crustacés d'eau douce / commerce d'animaux ornementaux / eaux intérieures / Europe centrale

\section{Introduction}

Freshwater crayfish are considered one of the major invasive alien species in aquatic ecosystems. As they often establish large populations, they affect much of the aquatic

\footnotetext{
*Corresponding author: rafal .maciaszek@kumakshrimp.pl
}

environment, including its biotic elements (Gherardi and Acquistapace, 2007; Twardochleb et al., 2013) and abiotic features of water systems as well (i.e., water turbidity), mainly due to burrowing (Correia and Ferreira, 1995). Numerous crayfish species were displaced into new locations all over the world as a result of aquaculture and fisheries (Savini et al., 2010). In many cases, freshwater crustaceans were also introduced via the pet trade (Patoka et al., 2014; Uderbayev 
et al., 2017; Deidun et al., 2018; Weiperth et al., 2019). Pet crayfish are often released into natural open waters if they outgrow their indoor aquarium or their owners become bored with them as well as a result of misinterpretation of inappropriately communicated legislations. Such activity has led to the introduction of at least several non-indigenous crayfish species (NICS), including several cambarids in European waters (Chucholl, 2013; Gál et al., 2017; Patoka et al., 2018).

In Europe, a handful of NICS have been recorded to date, mostly from North America (Kouba et al., 2014). One of them is the red swamp crayfish Procambarus clarkii (Girard, 1852) (Decapoda: Cambaridae). This species is native to Mexico and the southern USA and was introduced for the first time on the Iberian Peninsula, in the 1970s as a subject of aquaculture (Oficialdegui et al., 2019 and papers cited therein). It has subsequently become widely distributed across south-western part of the continent (Kouba et al., 2014). The northern and easternmost populations in Europe (such as around the city of Berlin, Budapest or Egerszalók) are so far relatively isolated (Chucholl, 2011a; Kouba et al., 2014; Gál et al., 2018; Szendőfi et al., 2018; Oficialdegui et al., 2019).

The species is listed among the worst invaders in Europe and worldwide and its negative impact on native organisms and communities is well documented on plants, invertebrates and vertebrates (Twardochleb et al., 2013). It is also considered as a pest in rice fields (Anastácio and Marques, 1997; Anastácio et al., 2005). As a carrier of Aphanomyces astaci Schikora, 1906, causative agent of 'crayfish plague' leading to mass mortalities of European astacids (Aquiloni et al., 2011; Svoboda et al., 2017), P. clarkii poses a special threat to native crayfish in Europe.

Despite being banned and listed as invasive species, in Poland, a member of European Union (EU), several color varieties of Procambarus clarkii are still a common pet. They are often available to buy on the internet, as well as being sold, kept and bred for sale in aquarium farms and shops. This species, often described as different, legally traded crayfish species, may not be identified by custom and veterinary inspectors (Patoka et al., 2017). It is also present on the pet market in the neighbouring EU countries such as Germany or Czech Republic as well as non-EU members such as Ukraine and Russia. In contrast to the European Union, there are no regulations governing licence or permission to keep the species in most Eastern Countries such as Ukraine, Russia or Kazakhstan as these animals are not prohibited over there. Thus, national and international pet trade can contribute to the dissemination of the species (Kotovska et al., 2016; Vodovsky et al., 2017; Uderbayev et al., 2017). No information is available about attempts to use this species in Polish aquaculture, however, its potential as a food source has been discussed in national aquaculture literature (Strużyński and Niemiec, 1999). Despite being common ornamental pet, only one record from Poland has been described to date (Smietana et al., 2018). However, due to lack of information dealing with population status, this observation cannot be considered as a reliable one. Procambarus clarkii is marked on IUCN Red List's (Crandall, 2010) geographic range map as "extant \& introduced (resident)" in western part of this country, nevertheless there is no data available that could confirm it and even at the same page, Poland is missing on the list of invaded European countries. According to WoRMS (2019) P. clarkii is also present in polish part of Baltic sea, but publications marked as a source of this data (Holdich et al., 2009; NEMESIS, 2014) do not prove it clearly and describe Polish water bodies as free of this species. Another record can be found in CABI database, where this crayfish was detected in Poland by DAISIE project (Gherardi and Panov, 2006) in 2011, however no data source is attached. All these records, presented on the internet, can be an effect of unintentional mistakes as well as attempts to mark only possible geographic range of $P$. clarkii based on confirmed presence of the species in German part of Oder River basin located at the border with Poland (Kouba et al., 2014; Oficialdegui et al., 2019).

In this contribution, we present new locations with confirmed presence of Procambarus clarkii in Poland.

\section{Material and methods}

\subsection{Localities}

Żerań Canal in Warsaw $\left(52.3127^{\circ} \mathrm{N}, 21.0013^{\circ} \mathrm{E}\right)$, is an artificial watercourse connecting the Zegrzyński Reservoir with the Vistula River (Fig. 1). The canal forms part of a power station cooling system, therefore contains heated waters allowing the survival of other non-native organisms during winter (i.e., often observed Central American freshwater Poecilidae representatives). It has a length of $17.6 \mathrm{~km}$ and a maximum depth of $2.5 \mathrm{~m}$. This site is known for the presence of the spiny-cheek crayfish Faxonius limosus (Rafinesque, 1817) (Strużyński, 2002) as well as being one of the most attractive fishing places in the capital.

Krasiński Garden in Warsaw $\left(52.2482^{\circ} \mathrm{N}, 21.0018^{\circ} \mathrm{E}\right)$ is a park with green area of 9.2 ha, located in central part of the city, ca. $1 \mathrm{~km}$ in a straight line from Vistula River (Fig. 1). Temporary water facilities based on artificial, concrete bed like small waterfall, stream and pond ( $0.2 \mathrm{ha})$ are one of the major attractions of the park. All of them are characterized by less than $1 \mathrm{~m}$ depth and are mostly used by aquatic birds and introduced ornamental fish such as Carassius auratus (Linnaeus, 1758). During summer season, algae bloom in pond is often observed which comes as an effect of visitors overfeeding birds with bread. If needed, pond is drained for winter season, cleaned and filled again in the spring. During this process water is pumped out and used for watering green areas in the park. If not previously caught by aquarists and anglers for its exotic looks, all aquatic organisms such as fish or macroinvertebrates found in drained pond, are moved by workers to the other water bodies (most likely the nearest ones) including natural oxbow lakes or rivers. Other animals, the mostly intensive coloured ones are presented to Zoological Garden or local aquarium shops (park's administration data, received 26 July 2019).

Dąbie Pond in Krakow $\left(50.0647^{\circ} \mathrm{N}, 19.9871^{\circ} \mathrm{E}\right)$, is a relatively small gravel pit ( $2.2 \mathrm{ha}$ ) with a maximum depth of $9 \mathrm{~m}$ (Fig. 1). Shallow parts of the pond are partially covered with the yellow water-lily Nuphar lutea Smith, whilst the bottom consists of sand, gravel, and mud. The site is located near Prądnik River (ca. $200 \mathrm{~m})$ and Vistula River (ca. $400 \mathrm{~m})$. The pond is known for the presence of the noble crayfish, Astacus astacus (Linnaeus, 1758). In 2014, an invasion of $F$. limosus was recorded, and further investigation showed the 


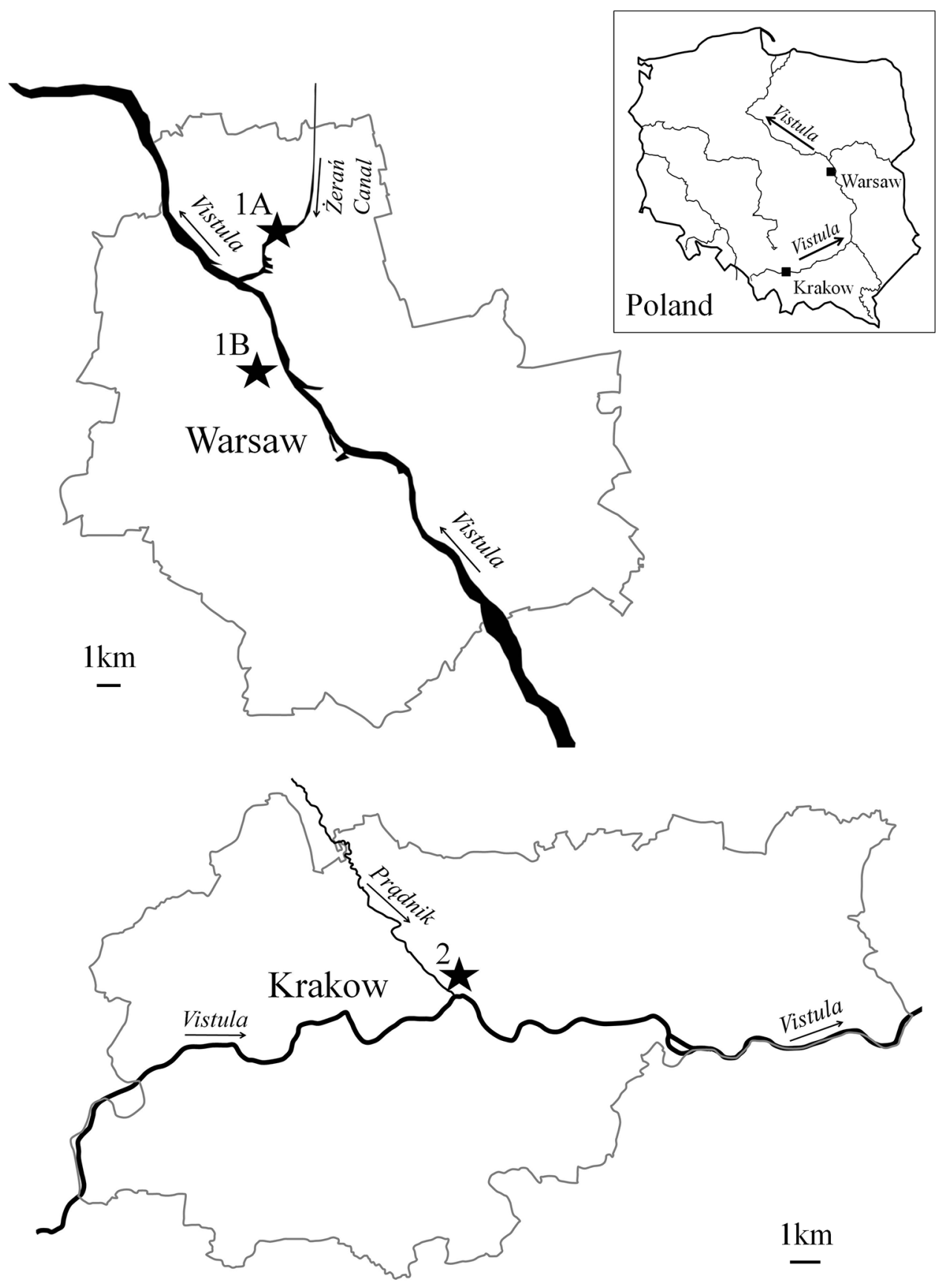

Fig. 1. Localisation of observation stations in Warsaw: Żerań Canal (1A), Krasiński Garden (1B) and Krakow: Dąbie Pond (2).

occurrence of both species (Stanek et al., 2015). Dąbie Pond is also an officially protected site, as it represented an important amphibian breeding site (Budzik and Żuwała, 2012), however, moderate fishing activity is permitted and the shoreline is available for recreation.

\subsection{Crayfish detection and identification}

In Żerań Canal, two night-time visual observations were made on 27 June 2018 and 9 September 2018 as a part of research on alien aquatic invertebrates.
On 8 May 2019 another inspection was made in Krasiński Garden park in Warsaw due to obtained information about crayfish accidentally found in the locality.

In Dąbie Pond, two observations lasting at least 30 minutes were made on 21 July 2018 and 6 September 2018 as a part of F. limosus visual encounter survey (see Bonk et al., 2019).

Additional inspections were made in November 2018 (Żerań Canal) and July 2019 (all locations). Each of the observations lasted for $c a .150$ minutes.

In all cases, detected crayfish were caught by a net or gathered by hand. All individuals were cleaned from 
R. Maciaszek et al.: Knowl. Manag. Aquat. Ecosyst. 2019, 420, 39

Table 1. Characteristics of Procambarus clarkii representatives detected in the wild in Poland. TL, total length; CL, carapax length.

\begin{tabular}{|c|c|c|c|c|c|}
\hline Locality & Date & Color form & Sex & $\mathrm{TL}[\mathrm{mm}]$ & $\mathrm{CL}[\mathrm{mm}]$ \\
\hline \multirow[t]{5}{*}{ Żerań Canal (Warsaw) } & 27.06.2018 & Orange & $\mathrm{F}$ & 75 & 49 \\
\hline & 27.06 .2018 & Orange & $\mathrm{F}$ & 70 & 45 \\
\hline & 27.06.2018 & Orange & $\mathrm{F}$ & 67 & 40 \\
\hline & 09.09 .2018 & Orange & $\mathrm{F}$ & 38 & 20 \\
\hline & 09.09.2018 & Wild (Red) & $\mathrm{F}$ & 29 & 12 \\
\hline \multirow[t]{2}{*}{ Krasiński Garden (Warsaw) } & 08.05 .2019 & White & $\mathrm{F}$ & 37 & 20 \\
\hline & 08.05 .2019 & White & $\mathrm{F}$ & 36 & 18 \\
\hline \multirow[t]{4}{*}{ Dąbie Pond (Krakow) } & 06.09 .2018 & Wild (Red) & M & 110 & 51 \\
\hline & 06.09 .2018 & Wild (Red) & $\mathrm{F}$ & 98 & 58 \\
\hline & 06.09 .2018 & Blue & $\mathrm{F}$ & 114 & 51 \\
\hline & 06.09 .2018 & Blue & NA & NA & NA \\
\hline
\end{tabular}

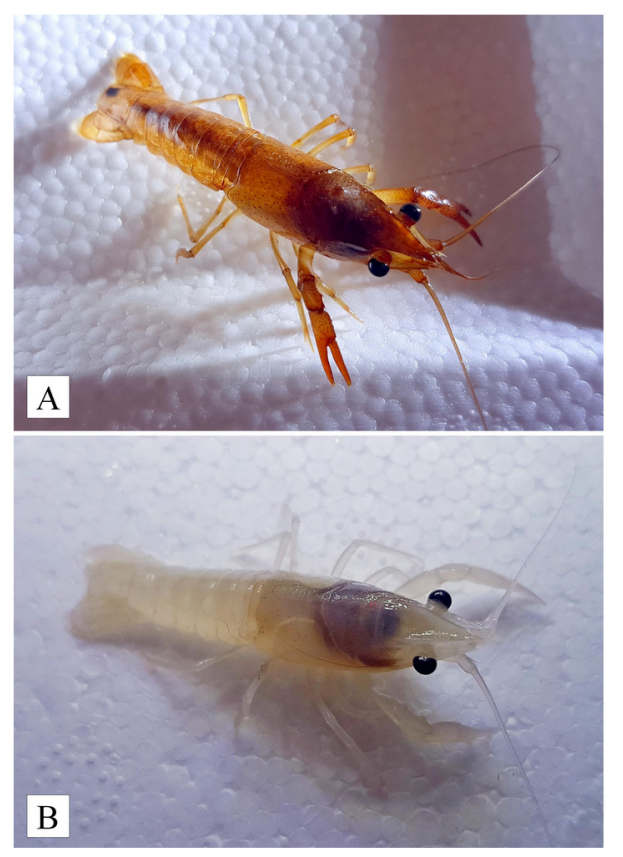

Fig. 2. Representatives of Procambarus clarkii Girard, 1852 found in: Żerań Channel - "Orange" specimen (A), Krasiński Garden "White" specimen (B).

sediments, measured and identified in laboratory using available scientific literature (Crocker, 1979; Wizen et al., 2008).

\section{Results}

Total of 11 crayfish identified as $P$. clarkii were collected at 3 locations in Poland. Five individuals, including juveniles, were caught during two inspections in Żerań Canal. Most of the crayfish were of 'orange' coloration, which is one of the typical ornamental forms of the species (Fig. 2a). One juvenile was classified as a 'wild' colouration type. During additional daily observations, $F$. limosus were also detected at that site.

Two specimens gathered by hand in Krasiński Garden park in Warsaw were identified as representatives of 'white'
P. clarkii variety (Fig. 2b). Both crayfish, covered with sediments were found few meters away from the pond, walking on the ground. No other cambarid species were noticed.

In Dąbie Pond, no crayfish were detected during the first inspection. The second deep netting on 6 September 2018 resulted in collecting four adult representatives of $P$. clarkii. All crayfish were found within several metres. Two color forms were recorded: two blue specimens and two 'wild' red specimens. Three of them (two males and one female) were caught, while the other one escaped.

The length of the specimens is shown in Table 1. In all localities burrowing activity was not observed.

\section{Discussion}

We provide new documented data on $P$. clarkii in open waters in Poland. The sites in Warsaw are located approximately $500 \mathrm{~km}$ eastward from well-established populations in Berlin, Germany while Krakow's Dąbie Pond is at a distance of 240 and $260 \mathrm{~km}$ from the nearest southern populations known from surroundings of Egerszalók and Budapest in Hungary (Gál et al., 2018; Szendőfi et al., 2018; Weiperth et al., 2019). Consequently, they are the most northeastward sites of the species in European natural ecosystems. This crayfish species is probably more widespread in this country, as well as eastern part of the continent, as it has been present in the ornamental pet trade from at least the year 2000 (Strużyński, 2007; Kotovska et al., 2016; Vodovsky et al., 2017; Uderbayev et al., 2017). Other potential sites may exist, however, few studies have been focussed on the distribution and occurrence of crayfish species in this region, and the real number of occurrences may therefore be underestimated.

Procambarus clarkii is a warm-water species, however, as Chucholl (2011b) predicted, it may be able to cope with cooler central and eastern European climates. Moreover, its invasion and establishment in temperate regions may be enhanced by anthropogenic global warming (Capinha et al., 2012). Therefore, even a single introduction could be potentially catastrophic for local ecosystems. In Europe, some warmwater invertebrates like freshwater shrimps of Atyidae family 
as well as asian pond mussel Sinanodonta woodiana (Lea, 1834) or the asian clam, Corbicula fluminea (Müller, 1774) were initially found in heated water close to power stations, however, after several years, some of them were able to also colonise cooler waters (Klotz et al., 2013; Maćkiewicz, 2013; Najberek et al., 2013; Chmielewski et al., 2017, Romanowski et al., 2017; Bonk et al., 2018; Jabłońska et al., 2018; Weiperth et al., 2019).

As we also found juvenile representatives of $P$. clarkii in Żerań Canal, we suggest that the population may be breeding, as in our opinion, there is a lower probability of juveniles being released into the natural environment than the adults. On the other hand, fertilised females could have been released at these sites and it is uncertain whether this species of crayfish would mate and produce offspring in Polish climate. Finally, absence of Procambarus representatives at this location during additional inspections in 2019 may be an effect of temporary crayfish activity, as this species may survive in local water temperature conditions which has been confirmed by carried experiments (Veselý et al., 2015), as well as stable populations known from locations characterised by similar temperature regime (Mueller, 2007; Haubrock et al., 2019).

Procambarus clarkii occurrence in Krasiński Garden and Dąbie Pond also seems to be the result of single introductions. These locations from Poland's biggest cities are characterised by higher risk of possible actions of irresponsible aquarists releasing unwanted pets (Perdikaris et al., 2012; Maciaszek et al., 2019a and cited papers therein) that are known from local artificial ponds (Maciaszek et al., 2019b; Maciaszek et al., 2019c) as well as natural reservoirs (Maciaszek and Sosnowski, 2019). According to relative small distance to open waters of Vistula River and ability of $P$. clarkii to traverse the land (Herrmann et al., 2018), both sites could become a potential source of further invasion (Chucholl, 2015; Patoka et al., 2016; Lipták et al., 2017), especially that passive transportation of this species by aquatic birds has been also documented (Anastácio et al., 2014).

Since $P$. clarkii is known for its negative impacts in new habitats, based on experience from other European countries, several potential threats for Polish natural ecosystems may be predicted (Śmietana et al., 2018). Most importantly, any direct impact of $P$. clarkii on other organisms causes indirect negative effects on the ecosystem via trophic cascades (Souty-Grosset et al., 2016). As a result of competition for the same environmental niche, transmission of crayfish plague, also enhancing the impact, presence of other NICS such as $F$. limosus, $P$. clarkii could have wiped out $A$. astacus from any water bodies, including exemplary Dąbie Pond (Stanek et al., 2015). Moreover, higher pressure on other macroinvertebrates, amphibians and fish could lead to unbalanced food chains and finally disappearance of smaller lakes and ponds due to their eutrophication (Reshetnikov, 2003; Souty-Grosset et al., 2016).

As the Polish climate is characterised by cold winters, warmer waters would be attractive for $P$. clarkii, therefore monitoring of any thermally polluted waters could facilitate early detection (Gál et al., 2018; Szendöfi et al., 2018). Furthermore, a major effort to eradicate NICS should be focused on such habitats, as they may become sources or 'stepping stones' for species expansion. On the other hand, as the ornamental pet trade and amateur aquariums are the major or possibly the only sources of this species in Poland, water bodies in large cities, where the number of $P$. clarkii kept as pets is presumably large, should be monitored, and any detected specimens in ponds should be eradicated. Mostly isolated, artificial ponds such as the one from Krasiński Garden can be easily controlled by collaboration with park's administration workers, who should be up to date with possible problems related to the area and be ready to raise the alarm in case NICS or any aquatic pet animals have been observed. Regular inspections should be provided during controlled water drainage from the pond. In case of NICS detection in open waters or other water bodies like Żeran Canal and Dąbie Lake, application of methods based on insecticides, even if effective, could be damaging to natural environment, especially to native crustaceans (Lidova et al., 2019). On the other hand, biological control represented by introduction of natural predators may be potentially dangerous to native crayfish as well as to amphibians. According to current knowledge on eradication actions, biotechnological methods such as Sterile Male Release Technique might be an effective temporary way for invasive crayfish management, as they are safe to environment and already tested mainly on P. clarkii (Manfrin et al., 2019; Sandodden, 2019). Environmentally safe methods allowing ultimate eradication of invasive crayfish are urgently needed.

\section{References}

Anastácio PM, Marques JC. 1997. Crayfish, Procambarus clarkii, effects on initial stages of rice growth in the lower Mondego River valley (Portugal). Freshw Crayfish 11: 608-617.

Anastácio AM, Correia JP, Menino L, da Silva M. 2005. Are rice seedlings affected by changes in water quality caused by crayfish? Ann Limnol - Int J Lim 41: 1-6.

Anastácio PM, Ferreira, MP, Banha F, Capinha C, Rabaça JE. 2014. Waterbird-mediated passive dispersal is a viable process for crayfish (Procambarus clarkii). Aquat Ecol 48: 1-10.

Aquiloni L, Martin MP, Gherardi F, Diéguez-Uribeondo J. 2011. The North American crayfish Procambarus clarkii is the carrier of the oomycete Aphanomyces astaci in Italy. Biol Invasions 13: 359-367.

Bonk M, Zając K, Lipińska AM. 2018. Rapid expansion of the Asian clam Corbicula fluminea (O. F. Müller, 1774): a new alien species in the mollusk community of the Vistula. Oceanol Hydrobiol St 47: $75-86$.

Bonk M, Bobrek R, Dołęga J, Strużyński W. 2019. Evaluation of visual encounter surveys of the noble crayfish, Astacus astacus and the spiny-cheek crayfish, Orconectes limosus. Fish Aquatic Life 27: $115-120$.

Budzik K, Żuwała K. 2012. Zagrożone płazy użytku ekologicznego "Staw Dąbski". Chrońmy Przyrodę Ojczysta 68: 20-25.

Capinha C, Anastácio P, Tenedório JA. 2012. Predicting the impact of climate change on the invasive decapods of the Iberian inland waters: an assessment of reliability. Biol Invasions 8: 1737 1751.

Chmielewski S, Romanowski J, Winczek M, Strużyński W. 2017. Records of the Chinese pond mussel Sinanodonta woodiana (Lea, 1934 ) in the middle Vistula river. Kulon 22: 149-152.

Chucholl C. 2011a. Disjunct distribution pattern of Procambarus clarkii (Crustacea, Decapoda, Astacida, Cambaridae) in an artificial lake system in Southwestern Germany. Aquat Invasions 6. 
Chucholl C. 2011b. Population ecology of an alien "warm water" crayfish (Procambarus clarkii) in a new cold habitat. Knowl Manag Aquat Ecosyst 401: 29.

Chucholl C. 2013. Invaders for sale: trade and determinants of introduction of ornamental freshwater crayfish. Biol Invasions 15: $125-141$.

Chucholl C. 2015. Marbled crayfish gaining ground in Europe: the role of the pet trade as invasion pathway. In Kawai T, Faulkes Z, Scholtz G, ed. Freshwater Crayfish: A global overview. Boca Raton: CRC Press, 83-114.

Correia AM, Ferreira O. 1995. Burrowing behavior of the introduced red swamp crayfish Procambarus clarkii (Decapoda: Cambaridae) in Portugal. J Crustacean Biol 15: 248-257.

Crandall KA. 2010. Procambarus clarkii. The IUCN Red List of Threatened Species 2010: e.T153877 A4557336. www.dx.doi.org/ 10.2305/IUCN.UK.20103.RLTS.T153877A4557336.en [accessed: 2019 Sep. 06]

Crocker DW. 1979. The crayfishes of New England. P Biol Soc Wash 92: 225-252.

Deidun A, Sciberras A, Formosa J, et al. 2018. Invasion by nonindigenous freshwater decapods of Malta and Sicily, central Mediterranean Sea. J Crustac Biol 38: 748-753.

Gál B, Kuř́íková P, Bláha M, Kouba A, Patoka J. 2017. Cambarellus patzcuarensis in Hungary: The first dwarf crayfish established outside of North America. Biologia 72: 1529-1532.

Gál B, Gábris V, Béla C, et al. 2018. Present distribution of the invasive red swamp crayfish Procambarus clarkii (Girard, 1852) and its effects on the fish fauna assemblages in some tributaries of the Hungarian section of the River Danube. Pisces Hungarici 12: $71-76$.

Gherardi F, Panov V. 2006. Procambarus clarkii. DAISIE 2011: www. europe-aliens.org/speciesFactsheet.do?speciesId=53452 [accessed: 2019 September 06]

Gherardi F, Acquistapace P. 2007. Invasive crayfish in Europe: The impact of Procambarus clarkii on the littoral community of a Mediterranean lake. Freshw Biol 52: 1249-1259.

Haubrock PJ, Kubec J, Veselý L, Buřič M, Tricarico E, Kouba A. 2019. Water temperature as a hindrance, but not limiting factor for the survival of warm water invasive crayfish introduced in cold periods. J Great Lakes Res 45: 788-794.

Herrmann A, Schnabler A, Martens A. 2018. Phenology of overland dispersal in the invasive crayfish Faxonius immunis (Hagen) at the Upper Rhine River area. Knowl Manag Aquat Ecosyst 419: 30.

Holdich DM, Reynolds JD, Souty-Grosset C, Sibley PJ. 2009. A review of the ever increasing threat to European crayfish from nonindigenous crayfish species. Knowl Manag Aquat Ecosyst 394395: 11 .

Jabłońska A, Mamos T, Gruszka P, Szlauer-Łukaszewska A, Grabowski M. 2018. First record and DNA barcodes of the aquarium shrimp, Neocaridina davidi, in Central Europe from thermally polluted River Oder canal, Poland. Knowl Manag Aquat Ecosyst 419: 14.

Klotz W, Miesen FW, Hüllen S, Herder F. 2013. Two Asian fresh water shrimp species found in a thermally polluted stream system in North Rhine-Westphalia, Germany. Aquat Invasions 8: 3.

Kotovska G, Khrystenko D, Patoka J, Kouba A. 2016. East European crayfish stocks at risk: arrival of non-indigenous crayfish species. Knowl Manag Aquat Ecosyst 417: 37.

Kouba A, Petrusek A, Kozák P. 2014. Continental-wide distribution of crayfish species in Europe: update and maps. Knowl Manag Aquat Ecosyst 413: 5.
Lidova J, Buric M, Kouba A, Velisek J. 2019. Acute toxicity of two pyrethroid insecticides for five non-indigenous crayfish species in Europe. Veterinární medicína 64: 125-133.

Lipták B, Mojžišová M, Grul'a D, et al. 2017. Slovak section of the Danube has its well-established breeding ground of marbled crayfish Procambarus fallax f. virginalis. Knowl Manag Aquat Ecosyst 418: 40.

Maciaszek R, Sosnowski W. 2019. First record of silver arowana Osteoglossum bicirrhosum Cuvier, 1928 (Osteoglossidae) from Central Poland. World Scientific News 117: 189-195.

Maciaszek R, Eberhardt M, Wilk S, Sosnowski W, Szpakowski B. 2019a. Alien aquarium fish species found in open waters of Poland with new record of Amazonian Red Pacu Piaractus brachypomus, Cuvier, 1818 (Serrasalmidae) from Bzura river. World Scientific News 126: 276-282.

Maciaszek R, Marcinek D, Eberhardt M, Wilk S. 2019b. Alien freshwater fish, Xiphophorus interspecies hybrid (Poeciliidae) found in artificial lake in Warsaw, Central Poland. World Scientific News 132: 291-299.

Maciaszek R, Skomorucha Ł, Eberhardt M. 2019c. Unsuccessfull introduction of the common pleco Hypostomus plecostomus Linnaeus, 1758 (Loricariidae) in artificial pond in Warsaw, Central Poland. World Scientific News 132: 308-312.

Maćkiewicz JJ. 2013. The first record of the Asian clam Corbicula fluminea (Bivalvia: Veneroida: Corbiculidae) in the upper Vistula (south Poland). Folia Malacol 21: 87-90.

Manfrin C, Souty-Grosset C, Anastácio P, Reynolds J, Giulianini P. 2019. Detection and control of invasive freshwater crayfish: From traditional to innovative methods. Diversity 11: 5.

Mueller KW. 2007. Reproductive habits of non-native red swamp crayfish (Procambarus clarkii) at Pine Lake, Sammamish, Washington. Northwest Sci 81: 246-251.

Najberek K, Solarz W, Król W, Pępkowska-Krol A, Strzałka M. 2013. Nowe stanowisko szczeżui chińskiej Sinanodonta woodiana w kompleksie stawów Przeręb koło Zatora. Chrońmy Przyrode Ojczysta 69: 155-158.

NEMESIS. 2014: www.invasions.si.edu/nemesis/ [accessed: 2019 Sep. 06]

Oficialdegui FJ, Clavero M, Sánchez MI, et al. 2019. Unravelling the global invasion routes of a worldwide invader, the red swamp crayfish (Procambarus clarkii). Freshw Biol 64: 1382-1400.

Patoka J, Petrtýl M, Kalous L. 2014. Garden ponds as potential introduction pathway of ornamental crayfish. Knowl Manag Aquat Ecosyst 414: 13.

Patoka J, Buřič M, Kolář V, et al. 2016. Predictions of marbled crayfish establishment in conurbations fulfilled: evidences from the Czech Republic. Biologia 71: 1380-1385.

Patoka J, Bláha M, Kalous L, Kouba A. 2017. Irresponsible vendors: Non-native, invasive and threatened animals offered for garden pond stocking. Aquat Conserv Mar Freshw Ecosyst 27: 692-697.

Patoka J, Magalhães ALB, Kouba A, Faulkes Z, Jerikho R, Vitule JRS. 2018. Invasive aquatic pets: failed policies increase risks of harmful invasions. Biodiversity Conserv 27: 3037-3046.

Perdikaris C, Kozák P, Kouba A, Konstantinidis E, Paschos I. 2012. Socio-economic drivers and non-indigenous freshwater crayfish species in Europe. Knowl Manag Aquat Ecosyst 404: 1.

Reshetnikov AN. 2003. The introduced fish, rotan (Perccottus glenii), depresses populations of aquatic animals (macroinvertebrates, amphibians, and a fish). Hydrobiologia 510: 83-90.

Romanowski J, Chmielewski S, Winczek M, Strużyński W. 2017. A record of the asian freshwater clam Corbicula fluminea in the Middle Vistula river. Kulon 22: 152-155. 
Sandodden R. 2019. Eradication of invasive alien crayfish: past experiences and further possibilities. In Veitch CR, Clout MN, Martin AR, Russel JC, West CJ, ed. Island invasives: scaling up to meet the challenge. Gland: IUCN, pp. 405-409.

Savini D, Occhipinti-Ambrogi A, Marchini A, Tricarico E, Gherardi F, Olenin S, Gollasch S. 2010. The top 27 animal alien species introduced into Europe for aquaculture and related activities. $J$ Appl Ichthyol 26: 1-7.

Souty-Grosset C, Anastacio PM, Aquiloni L, et al. 2016. The red swamp crayfish Procambarus clarkii in Europe: impacts on aquatic ecosystems and human well-being. Limnologica 58: 78-93.

Stanek Ł, Wiehle D, Szybak F. 2015. Inwentaryzacja raków występujących na terenie użytku ekologicznego Staw Dąbski. Kraków: Wydział Kształtowania Środowiska UMK, 3-21.

Strużyński W, Niemiec T. 1999. Procambarus clarkii - potencjalnym zagrożeniem naszych wód. Przeglad Rybacki 5: 29-34.

Strużyński W. 2002 Rak pręgowaty (Orconectes limosus Rafinesque 1817) w wodach Niziny Mazowieckiej (Spiny cheek crayfish Orconectes limosus Rafinesque 1817 in Mazovia Lowland Poland). PhD thesis - Warsaw University Life Sciences.

Strużyński W. 2007. Raki (Crayfish). Monografie przyrodnicze. Świebodzin: Wydawnictwo Klubu Przyrodników, 1-169.

Svoboda J, Mrugała A, Kozubíková-Balcarová E, Petrusek A. 2017. Hosts and transmission of the crayfish plague pathogen Aphanomyces astaci: a review. J Fish Diseases 40: 127-140.

Śmietana P, Bonk M, Solarz W. 2018. Orconectes limosus (Rafinesque, 1817) - Karta informacyjna gatunku. Source:
Generalna Dyrekcja Ochrony Środowiska. www.projekty.gdos. gov.pl/igo [accessed: 2019 Apr. 04].

Szendőfi B, Bérces S, Csányi B, et al. 2018. Occurrence of exotic fish and crayfish species in Barát and Dera creeks and their adjacent section of the River Danube. Pisces Hungarici 12: 47-51.

Twardochleb LA, Olden JD, Larson ER. 2013. A global meta-analysis of the ecological impacts of nonnative crayfish. Freshw Sci 32: $1367-1382$.

Uderbayev T, Patoka J, Beisembayev R, Petrtýl M, Bláha M, Kouba A. 2017. Risk assessment of pet-traded decapod crustaceans in the Republic of Kazakhstan, the leading country in Central Asia. Knowl Manag Aquat Ecosyst 418: 30.

Veselý L, Buřič M, Kouba A. 2015. Hardy exotics species in temperate zone: can "warm water" crayfish invaders establish regardless of low temperatures? Sci Rep 5: 16340.

Vodovsky N, Patoka J, Kouba A. 2017. Ecosystem of Caspian Sea threatened by pet-traded non-indigenous crayfish. Biol Invasions 19: 2207-2217.

Weiperth A, Gábris V, Danyik T, Farkas A, Kuř́ková P, Kouba A, Patoka J. 2019. Occurrence of non-native red cherry shrimp in European temperate waterbodies: a case study from Hungary. Knowl Manag Aquat Ecosyst 420: 9.

Wizen G, Galil B, Shlagman A, Gasith A. 2008. First record of red swamp crayfish, Procambarus clarkii (Girard, 1852) (Crustacea: Decapoda: Cambaridae) in Israel-too late to eradicate. Aquat Invas 3: $181-185$.

WoRMS. 2019. www.marinespecies.org/aphia.php?p=taxdetail s\&id=465540 [accessed: 2019 Sep. 06]

Cite this article as: Maciaszek R, Bonk M, Strużyński W. 2019. New records of the invasive red swamp crayfish Procambarus clarkii (Girard, 1852) (Decapoda: Cambaridae) from Poland. Knowl. Manag. Aquat. Ecosyst., 420, 39. 